\title{
AKIBAT HUKUM PENAHANAN DAZAH OLEH BADAN USAHA DITINJAU DARI PERSPEKTIF HUKUM PERJANJIAN
}

\author{
Wayan Ardi Indra Jaya, Anak Agung Sagung Laksmi Dewi, Ni Made Puspasutari Ujianti \\ Fakultas Hukum, Universitas Warmadewa, Denpasar-Bali, Indonesia \\ Indrajayaardi@gmail.com, laksmidewi2909@gmail.com,puspautariijianti@gmail.com
}

\begin{abstract}
Abstrak
Penahanan ijazah merupakan tindakan yang dilakukan oleh badan atau pelaku usaha untuk memindahkan kekuasaan benda surat berharga ijazah milik pekerja sebagai jaminan pekerja kepada perusahaan. Sesuai Undang-undang ketenagakerjaan tidak terdapat aturan yang mengatur tentang boleh atau tidaknya menahan ijazah milik pekerja tetapi dalam aturan hukum perdata yang mengatur perjanjian kerja terdapat asas kebebasan berkontrak yang mana memberikan kebebasan dalam menentukan klausla-klausla hukum bagi para pihak sepanjang tidak melanggar norma hukum, kesusilaan, dan nilai nilai yang ada dimasyarakat, hal inilah yang kemudian menjadi dasar hukum bagi pelaku usaha dalam menahan ijazah milik pekerja. Tujuan penelitian ini untuk mengkaji pengaturan hukum terhadap penahanan ijazah sebagai syarat bekerja dan akibat hukum dari adanya tindakan penahanan ijazah oleh badan usaha ditinjau dari pers pektif hukum perjanjian. Penelitian ini menggunakan penelitian hukum normatif dengan pendekatan konseptual, kasus dan perundang-undangan. Adapun data yang digunakan yaitu data primer dan sekunder yang diperoleh melalui teknik wawancara dan kepustakaan. Hasil penelitian mengungkapkan bahwa pengaturan hukum penahanan ijazah hanya ada pada hukum perjanjian yaitu badan usaha dan pekerja sepakat untuk membentuk suatu hubungan kerja. Dasar hukum ketenagakerjaan baik warga negara Indonesia atau asing diatur dalam U-u No 13 Tahun 2003 Tentang. Akibat hukum yang mengikatnya dalam hal apapun yakni pelaku usaha dapat digugat secara perdata karena ijazah anda tidak kunjung dikembalikan setelah ganti rugi dibayarkan maka pekerja dapat menggugat badan usaha tersebut atas dasar wanprestatie sebagaimana diatur dalam Pasal 1243 KUH Perdata dan atau badan usaha dap at dijerat pasal penggelapan yang diatur dalam Pasal 372 KUHP.
\end{abstract}

Kata Kunci: Kesepakatan Kerja, Penahanan Ijazah, Perusahaan

\begin{abstract}
Detention of a diploma is an action taken by a business entity or actor to transfer the power of a certificate object belonging to a worker as a worker's guarantee to the company. According to the laborlaw, there are no rules governing whether or not it is permissible to withhold certificates belonging to workers, but in the civil law rules governing work agreements, there is the principle of freedom of contract which provides freedom in determining legal clauses for the parties as long as they do not violate legal norms. decency, and values that exist in society, this is what then becomes the legal basis for business actors in withholding certificates belonging to workers. The purposes of this study are to examine the legal arrangements for the detention of diplomas as a condition of work and the legal consequences of the act of detention of diplomas by business entities in terms of the perspective of contract law. This study uses normative legal research with a conceptual approach, cases and legislation. The data used are primary and secondary data obtained through interview and library techniques. The results of the study reveal that the legal arrangement for the detention of diplomas only exists in contract law, namely the business entity and the worker agree to form an employment relationship. The legal basis for employment, whether Indonesian citizens or foreigners, is regulated in Law No. 13 of 2003 concerning. The legal consequence that binds it in any case is that the business actor can be sued in a civil manner because your diploma has not been returned after the compensation has been paid, the worker can sue the business entity on the basis of wanprestie as regulated in Article 1243 of the Civil Code and or the business entity can be charged with embezzlement regulated in Article 372 of the Criminal Code.
\end{abstract}

Keywords: Work Agreement, Diploma Detention, Company 


\section{PENDAHULUAN}

Pembangunan nasional yang saat ini gencar dilakukan oleh negara-negara yang tersebar di seluruh dunia termasuk di Indonesia berfokus dibeberapa bidang yakni, pendidikan, politik dan keamanan, sosial dan budaya, dan yang tidak kalah penting yakni bidang perekonomian (Hapsari, 2019). Perekonomian merupakan tulang punggung kehidupan masyarakat, tidak sedikit orang yang menggantungkan mata pencahariannya di bidang ekonomi (Sari, 2016). Untuk menjalankan roda perekonomian setidaknya dibutuhkan pelaku usaha, konsumen, dan pekerja (Romdonny \& Rosmadi, 2018). Saat ini ditengah ketatnya persaingan usaha banyak kita jumpai pelaku usaha yang menggunakan cara-cara yang tidak benar dalam merekrut pekerja. Karena itu penting bagi pekerja untuk mengetahui perlindungan hukum bagi pekerja. Dasar hukum perlindungan hukum penahanan ijazah pekerja di Indonesia adalah Pasal 27 ayat 2 Undang-undang Negara Republik Indonesia Tahun 1945 dan Undang-undang No 13 Tahun 2003 tentang ketenagakerjaan.

Sampai saat ini, banyak kita jumpai pemberi kerja atau badan usaha yang menjadikan syarat khusus dalam materi pencarian kerja, seperti contoh adanya klausula pekerja bersedia memberi ijazahnya kepada pemberi kerja atau badan usaha. Ijazah merupakan bukti otentik atau surat berharga yang berisi bukti bahwa seseorang telah menempuh pendidikan yang didalamnya melekat hak milik seseorang yang diakui oleh hukum. Umumnya, saat pekerja ingin melamar suatu pekerjaan terdapat persyaratan umum dan khusus sebagai informasi awal salah satu persyaratan khusus yang sering diminta badan usaha yakni penahanan ijazah asli milik pekerja. Hal ini dimaksudkan untuk mencegah kerugian badan usaha yang ditimbulkan pekerja seperti berhenti bekerja secara sepihak, atau hal lainnya. Disisi lain peraturan ini bisa dikatakan berlawanan dengan hak asasi seseorang untuk mencari pekerjaan yang layak. Jika melihat pada ketentuan Undang-undang Ketenagakerjaan yakni Undangundang Republik Indonesia Nomor 13 Tahun 2003 beserta peraturan pelaksanaannya, tidak terdapat peraturan yang mengatur tentang penahanan ijazah asli. Hal ini mengakibatkan adanya kekosongan hukum terkait boleh atau tidaknya dilakukan penahanan ijazah. Selain itu pada beberapa kasus terdapat badan usaha yang melakukan wanprestasi perjanjian kerja dengan tidak mengembalikan dana tetap menahan ijazah pekerja karena satu dan lain hal (Gede \& Putu, 2018). Penelitian lain mengungkapkan bahwa dalam rekrutmen karywan hendaknya badan usaha wajib mengikuti prosedur sesuai dengan Undang-undang ketenagakerjaan dan apa bila perusahaan memberhentikan pekerja sebelum kontrak kerja berakhir, maka wajib membayarkan hak dari karyawan tersebut (Slamet, 2013) \& (Maslikan \& Sukarmi, 2018).

Walaupun kasus ini telah banyak dikaji penelitian terdahulu, namun sampai saat ini masih terus terjadi tindak wanprestasi baik yang dilakukan oleh badan usaha bahkan karyawan itu sendiri. Berdasarkan hal tersebut, maka penelitian ini dilakukan dengan tujuan untuk mengetahui pengaturan hukum terhadap penahanan ijazah sebagai syarat bekerja dan akibat hukum dari adanya tindakan penahanan ijazah oleh badan usaha ditinjau dari perspektif hukum perjanjian.

\section{METODE PENELITIAN}

Penelitian ini menggunakan metode penelitian hukum normatif yaitu kajian memfokuskan pada kajian hukum positif yang tertulis meliputi sumber hukum primer seperti peraturan Perundang-undangan dan sumber hukum sekunder seperti buku, literatur, karya tulis ilmiah lainnya kemudian bahan hukum yang terkait dengan mereview atau mengulas produk dan jasa dianalisis dengan metode interpretasi hukum, argumentasi hukum, dan konstruksi hukum (Ahmad, 2008). Karena data penelitian ini adalh terkait pengaturan perundang-undangan maka pendekatan yang digunakan adalah pendekatan peraturan perundang-undangan (statuteapproach), pendekatan konseptual (conceptual approach), dan pendekatan kasus (case approach) (Sugijono, 2011). Data penelitian diperoleh melalui teknik wawancara dan kepustakaan. Selanjutnya data diolah dan dianalisis secara kualitatif deskriptif.

\section{HASIL DAN PEMBAHASAN}

\section{Pengaturan hukum terhadap penahanan ijazah sebagai syarat bekerja}

Ditengah melonjaknya angka pertumbuhan masyarakat memang membawa banyak dampak positif bagi kemajuan bangsa. Hal ini juga bisa menjadi boomerang yang berakhir negatif seperti meningkatnya persaingan baik di bidang usaha atau mencari pekerjaan, dengan melonjaknya jumlah pencari kerja maka perusahaan juga meningkatkan standarisasi untuk para karyawannya salah satu contoh dengan menahan ijazah asli milik pekerja (Agus Riyanto. 2018). Dasar hukum perlindungan 
hukum mereview atau mengulas produk di Indonesia adalah Pasal 27 ayat 2 Undang-undang Negara Republik Indonesia Tahun 1945 dan Undang-undang No 13 Tahun 2003 tentang ketenagakerjaan. Dalam hukum ketenagakerjaan pekerja adalah setiap orang yang bekerja pada orang lain dengan menerima upah atau imbalan dalam bentuk lain. Imbalan dalam bentuk lain yang dimaksud adalah berupa barang atau benda yang nilainya ditentukan atas dasar kesepakatan pengusaha dan pekerja.

Biasanya dalam dunia kerja, untuk menjamin standarisasi mutu dari suatu badan usaha diperlukan adanya aturan yang menjelaskan persyaratan administrasi untuk mendaftar pekerjaan seperti usia pekerja, latar belakang pendidikan pekerja, pengalaman bekerja, fasilitas pribadi milik pekerja, dan kesanggupan bekerja mengikuti aturan yang telah ditetapkan. Hal ini bisa kita jumpai dalam poster atau iklan yang disebarluaskan oleh pemberi kerja pada media offline seperti kertas, spanduk, baliho atau media online seperti instagram, whatsapp, website dan yang lainnya. Untuk menarik perhatian pembaca juga tenaga kerja biasanya pemberi kerja meningkatkan kualitas design dari iklan guna menjaring tenaga kerja semaksimal mungkin dan bisa memilih pekerja dengan kualitas terbaik.

Dalam rangka meningkatkan kualitas produk dari badan usaha disamping membutuhkan tenaga kerja Indonesia, juga memerlukan tenaga kerja asing yang mempunyai kemampuan sesuai kompetensinya dan mumpuni untuk memberikan berbagi ilmu (sharing acknowledge) \& berbagi pengalaman (sharing experience) agar kompetensi tenaga kerja Indonesia bisa meningkat dan bisa bersaing di pasar global. Sesuai dengan aturan hukum yang ada di Indonesia hanya badan hukum tertentu yang dapat menggunakan tenaga kerja asing diantaranya Instansi milik pemerintah, Badanbadan usaha internasional, Perwakilan negara milik asing, Organisasi internasional, Kantor perwakilan dagang milik asing, kantor perwakilan perusahaan milik asing, kantor perwakilan berita milik asing, Perusahaan swasta milik asing, Badan hukum dalam bentuk PT ataupun Yayasan, Lembaga sosial, lembaga keagamaan, lembaga pendidikan dan kebudayaan, Badan usaha jasa impresariat.

Persyaratan tenaga kerja asing untuk dapat bekerja di Indonesia mempunyai latar belakang pendidikan yang sesuai dengan posisi yang akan ditempati TKA, mempunyai sertifikat kompetensi keahlian atau memiliki pengalaman kerja yang sesuai dengan posisi yang akan ditempati TKA (minimal 5 tahun), membuat surat pernyataan wajib mengalihkan keahliannya kepada TKI pendamping, mempunyai NPWP (dengan masa kerja lebih dari 6 bulan), mempunyai polis asuransi milik badan hukum Indonesia, menjadi peserta jaminan sosial nasional Indonesia (dengan masa kerja lebih dari 6 bulan). Setelah semua persyaratan yang diperlukan terpenuhi barulah izin tenaga kerja asing bisa diproses. Pengurusan izin tenaga kerja asing meliputi beberapa tahapan, berikut adalah garis besarnya Registrasi untuk memperoleh antrian online RPTKA, Isi form dokumen RPTKA, Unggah dokumen RPTKA, Verifikasi RPTKA dan penjadwalan ekspose oleh KEMENAKER, Pengesahan RPTKA, Pemegang RPTKA.

Untuk menjamin semua pihak mengikuti semua prosedur yang ada maka perlu diatur sanksi bagi para pihak yang melanggar ketentuan peraturan Perundang-undangan yakni:

a. Penundaan pelayanan diberikan apabila badan usaha TKA tidak memfasilitasi TKA dalam program asuransi, jaminan sosial nasional \& tidak melaporkan penggunaan TKA dan pendidikan pelatihan tenaga kerja pendamping

b. Penghentian sementara perizinan TKA diberikan jika TKA tidak memiliki RPTKA yang telah disahkan menteri atau pejabat yang ditunjuk, tidak menunjuk tenaga kerja pendamping, tidak melaksanakan pendidikan dan pelatihan bagi tenaga kerja pendamping, tidak memfasilitasi pendidikan dan pelatihan terhadap tenaga kerja pendamping.

c. Pencabutan Notifikasi diberikan apabila mempekerjakan TKA pada jabatan yang dilarang diisi oleh TKA.

d. Sanksi lain diberikan sesuai dengan peraturan perundang-undangan di mana sanksi diberikan tergantung seberapa berat pelanggaran yang dilakukan.

Dalam praktek yang ada dilapangan baik TKI atau TKA wajib terikat dalam suatu perjanjian

kerja. Unsur-unsur yang harus ada dalam perjanjian kerja yakni

a) Adanya pekerjaan artinya suatu tanggung jawab menyelesaikan perintah atau tugas yang diberikan oleh pemberi kerja kepada pekerja.

b) Adanya unsur di bawah perintah. Perintah yang dimaksud merupakan kewajiban menghormati dan 
melaksanakan tugas yang diberikan oleh atasan atau pemberi kerja.

c) Adanya upah tertentu. Upah merupakan balas jasa dari tanggung jawab yang telah diselesaikan oleh pekerja baik berupa tunai atau non tunai. Untuk menjamin kehidupan yang layak bagi pekerja pemerintah dalam hal ini pejabat yang berwenang wajib mengatur upah minimum yang harus dibayarkan pemberi kerja kepada pekerja.

d) Adanya waktu. Ketika melakukan suatu pekerjaan harus ditentukan waktu jam kerja sesuai perjanjian dan perundang undangan yang berlaku dengan tujuan pekerja tidak bisa bekerja dalam waktu yang sesuai keinginannya sendiri sendiri.

Selain unsur perjanjian, syarat sahnya perjanjian juga menjadi dasar keabsahan yuridis bagi perjanjian kerja yang dibuat atas dasar adanya kesepakatan kedua belah pihak, kemampuan atau kecakapan melakukan perbuatan hukum, adanya pekerjaan yang diperjanjikan, pekerjaan yang diperjanjikan tidak bertentangan dengan ketertiban umum, kesusilaan, dan peraturan perundangundangan (Siska et al., 2019); (Ida Bagus Wyasa Putra. 2017)

Bentuk Perjanjian Kerja bisa dibuat dalam bentuk lisan dan tertulis, tetapi agar mempunyai kekuatan hukum yang mengikat bagi para pihak disarankan membuat perjanjian yang dibuat secara tertulis sekurang-kurangnya memuat

1. Nama, alamat perusahaan, dan jenis usaha

2. Nama, jenis kelamin, umur, dan alamat para pihak

3. Jabatan atau jenis pekerjaan

4. Tempat pekerjaan

5. Besarnya upah dan cara pembayarannya

6. Syarat-syarat kerja yang memuat hak dan kewajiban pengusaha dan pekerja/buruh

7. Mulai dan jangka waktu berlakunya perjanjian kerja

8. Tempat dan tanggal perjanjian kerja dibuat

9. Tanda tangan para pihak dalam perjanjian kerja.

Jenis perjanjian kerja dapat dibedakan menjadi du yaitu perjanjian kerja untuk waktu tertentu

Perjanjian kerja untuk waktu tertentu (PKWT) atau yang lebih dikenal dengan sistem kerja kontrak ini dibuat untuk mengayomi hak hak yang dimiliki oleh pekerja untuk melaksanakan tanggung jawab pekerjaannya sesuai dengan waktu yang telah disepakati dalam perjanjian kerja dan perjanjian kerja untuk waktu tidak tertentu atau yang lebih dikenal dengan sistem kerja tetap dapat mensyaratkan masa percobaan kerja paling lama 3 bulan. Setelah 3 bulan bekerja berhak diangkat menjadi pekerja tetap di dalam badan usaha tersebut sesuai dengan perjanjian kerja yang dibuat. Dalam hal berakhirnya perjanjian ditentukan apabila terpenuhinya syarat syarat sebagai berikut yakni Pekerja meninggal dunia, Berakhirnya jangka waktu perjanjian kerja, Adanya putusan pengadilan atau putusan atau penetapan lembaga penyelesaian perselisihan hubungan industrial yang telah mempunyai kekuatan hukum tetap atau adanya keadaan atau kejadian tertentu yang dicantumkan dalam perjanjian kerja, peraturan perusahaan, atau perjanjian kerja bersama yang dapat menyebabkan berakhirnya hubungan kerja.

Klausula penahanan ijazah pada dasarnya belum diatur dalam undang undang ketenagakerjaan, karena itu para pemberi kerja cenderung menggunakan standar operasional prosedur (SOP) yang mereka miliki untuk dijadikan dasar hukum penahanan ijazah dalam klausula perjanjian kerja. Sebagai contoh kasus nyata penahanan ijazah ini dimana adik sepupu penulis mencoba melamar kerja sebagai nailist (Pegawai kutek tangan dan kaki) di salah satu badan usaha yang bernama nail henna yang terletak di jalan ahmad yani utara (selatan polsek Denpasar utara), yang mana dalam perjanjian kerja yang diberikan memuat bahwa pekerja harus menyerahkan ijazah terakhir asli sebagai syarat bekerja. Mengingat tindakan penahanan ijazah bertentangan dengan hak asasi manusia, maka untuk memberikan perlindungan terhadap Hak Asasi Manusia atas hak atas pekerjaan dan penghidupan yang layak, maka pemerintah diharapkan membentuk peraturan terkait dengan penahanan ijazah asli pekerja sehingga peraturan ini dapat digunakan sebagai dasar atau bagian dalam kebebasan berkontrak.

Beberapa perusaahaan di tali sendiri pemerintah daerah belum mengatur hal ini sebagai produk hukum, yang mana menyebabkan banyak pihak yang menyalahgunakan kesempatan ini demi kepentingan nya pribadi, sebagai perbandingan dalam mengisi kekosongan hukum yang masih belum diatur, di Jawa Timur sudah ada Peraturan Daerah Jawa Timur No 8 Tahun 2016 tentang 
penyelenggaraan ketenagakerjaan. Pasal 42 Perda Jawa Timur No 8 Tahun 2016 menyebutkan Pengusaha dilarang menahan atau menyimpan dokumen asli yang sifatnya melekat pada pekerja sebagai jaminan. Dalam penjelasannya dijelaskan bahwa Dokumen asli yang dimaksud adalah kartu tanda penduduk (KTP), surat izin mengemudi (Sim), akte kelahiran, kartu keluarga, paspor, jazah dan sertifikat.

Berdasarkan hal diatas, dapat menyimpulkan di jawa timur ada payung hukum yang melindungi tenaga kerja atau pekerja di jawa timur terhadap penahanan ijazah yang dilakukan oleh pengusaha. Dengan adanya perda di jawa timur ini berharap pemerintah daerah menaruh perhatian untuk membentuk aturan yang mengatur penahanan ijazah agar tidak terjadi permasalahan yang merugikan salah satu pihak dikemudian hari.

\section{Akibat Hukum dari Adanya Tindakan Penahanan Ijazah oleh Badan Usaha Ditinjau dari Perspektif Hukum Perjanjian}

Penahanan ijazah dibeberapa perusahaan tertentu berfungsi sebagai jaminan terdapat peralihan hak penguasaan ijazah yang didasari oleh alasan tertentu yang kemudian menghasilkan perjanjian antara pekerja dan badan usaha (Sunggono \& Harianto, 2010). Ada beberapa alasan yang mempengaruhi badan usaha menahan ijazah milih pekerja yakni

1. Badan usaha mempunyai posisi yang lebih tinggi.

Banyaknya jumlah pekerja tidak sebanding dengan lowongan pekerjaan yang dibutuhkan oleh badan usaha. Yang mana berakibat persaingan diantara para pekerja sangat ketat dan badan usaha merasa dibutuhkan diatas angin sehingga mereka terlihat bebas menentukan isi dari perjanjian kerja kepada pekerjanya.

2. Ijazah sebagai jaminan pekerja agar tidak semena mena dalam menjalankan kewajibannya.

Pada hakekatnya benda yang dapat dijadikan sebagai jaminan umum merupakan benda yang mempunyai kriteria sebagai berikut yakni benda tersebut mempunyai nilai ekonomis (dapat dinilai dengan mata uang yang sah) dan benda tersebut dapat dipindah tangankan haknya kepada pihak lain. Dari kedua hal ini dapat kita simpulkan bahwa ijazah merupakan surat berharga yang tidak bisa digunakan sebagai jaminan karena tidak mempunyai nilai ekonomis.

3. Mencegah kerugian perusahaan karena sering nya keluar masuk pekerja. Apabila kita melihat lebih dalam alasan penahanan ijazah oleh badan usaha, biasanya kita bisa lihat bahwa badan usaha tersebut mempunyai aktifitas pekerjaan yang padat yang mana berarti badan usaha tersebut akan kerepotan apabila mempunyai pekerja yang terus berganti ganti karena memakan waktu, tenaga, dan biaya. Untuk mencegah kemungkinan terburuk itulah maka pihak badan usaha memberlakukan perjanjian kerja dengan penahanan ijazah agar setidaknya pekerja dapat bertahan lebih lama sesuai waktu yang ditentukan.

Dalam praktek yang terjadi di masyarakat tidak semua hal akan berjalan sesuai rencana, banyak kita lihat pelaku usaha yang menahan ijazah milik pekerja dan tidak mengembalikan nya sesuai jangka waktu perjanjian, hal ini tentu mempunyai akibat hukum bagi badan usaha yang mana menguasai ijazah tersebut baik secara perdata maupun pidana. Penyelesaian sengketa yang dapat digunakan diantaranya metode litigasi dan non litigasi.

Menurut Priyatna Abdurrasyid, penyelesaian sengketa secara nonlitigasi merupakan metode penyelesaian masalah yang berdasar pada asas kekeluargaan, Nurani dan aturan hukum yang mana akan menghasilkan solusi bersifat win win solution sehingga para pihak akan secara sukarela mentaati kesepakatan yang telah dibuat (Hermansyah, 2014). Selain itu dengan menggunakan metode non litigasi para pihak mendapat keuntungan lain diantaranya kerahasiaan data pribadi, biaya perkara yang terjangkau, dan tetap menjaga hubungan baik. Metode penyelesaian sengketa non litigasi dibagi menjadi 3 bagian yakni (1) negosiasi, yaitu metode untuk menyelesaikan suatu perkara melalui diskusi yang bersifat kekeluargaan (musyawarah) secara langsung antara pihak-pihak yang bersengketa yang hasilnya diterima oleh para pihak tersebut. (2) mediasi merupakan metode penyelesaian masalah dengan mengikutsertakan pihak ketiga yang bersifat netral. Pihak ketiga ini berfungsi sebagai penengah untuk mencari jalan keluar yang tidak merugikan para pihak. (3) arbitrase merupakan metode terakhir penyelesaian sengketa di luar peradilan dengan melibatkan pihak arbiter yang dipilih dan diberi kewenangan mengambil keputusan berdasarkan pada perjanjian arbitrase yang dibuat oleh para pihak.

Apabila upaya terakhir penyelesaian sengketa diluar pengadilan yakni arbitrase tidak juga bisa 
memecahkan masalah maka badan usaha dapat digugat secara perdata karena ijazah pekerja tidak kunjung dikembalikan setelah ganti rugi dibayarkan, maka pekerja dapat menggugat perusahaan tersebut atas dasar wanprestasi. Apabila hal tersebut juga tidak efektif maka badan usaha dapat dijerat pasal tindak penggelapan diatur dalam Pasal 372 KUHP. Yang termasuk penggelapan adalah perbuatan mengambil barang milik orang lain sebagian atau seluruhnya) di mana penguasaan atas barang itu sudah ada pada pelaku, tapi penguasaan itu terjadi secara sah. Misalnya, penguasaan ijazah oleh badan usaha terjadi karena pekerja menyerahkannya sebagai jaminan. Tujuan dari penggelapan adalah memiliki barang atau uang yang ada dalam penguasaannya yang mana barang/uang tersebut pada dasarnya adalah milik orang lain.

\section{SIMPULAN DAN SARAN}

\section{Simpulan}

Dari hasil analisis dan pembahasan di atas maka ada beberapa kesimpulan yang dapat dibuat yaitu Pengaturan hukum penggunaan ijazah saat ini hanya ada pada hukum perjanjian dimana badan usaha dan pekerja sepakat untuk membentuk suatu hubungan kerja. Pada umumnya ijazah adalah sebuah surat berharga yang berisi keterangan Pendidikan terakhir atau tanda bukti pernah mengikuti pelatihan untuk meningkatkan kapasitas dan kemampuan seseorang. Saat ini ijazah menjadi persyaratan administrasi apabila seseorang ingin melanjutkan pendidikannya atau mencari pekerjaan. Akibat hukum penahanan Ijazah. Pelaku usaha dapat digugat secara perdata karena ijazah anda tidak kunjung dikembalikan setelah ganti rugi dibayarkan maka pekerja dapat menggugat badan usaha tersebut atas dasar wanprestatie sebagaimana diatur dalam Pasal 1243 KUH Perdata dan atau badan usaha dapat dijerat pasal penggelapan yang diatur dalam Pasal 372 KUHP.

\section{Saran}

Sesuai dengan hasil penelitian ini, maka ada beberapa saran yang perlu disampaikan yaitu Untuk memberikan perlindungan kepada masyarakat di Negara Indonesia tanpa terkecuali, maka aparat negara baik di bagian eksekutif, legislatif, dan yudikatif harus saling bahu membahu untuk menjamin adanya pengaturan hukum tentang penahanan ijazah beserta sanksi yang memberatkannya agar tidak ada pihak yang merasa diperlakukan secara diskriminasi. Dalam menegakkan peraturan hukum perundang undangan maka aparat hukum negara dalam hal ini kepolisian wajib untuk melindungi kepentingan korban penahanan ijazah agar hak hak nya dapat dikembalikan dan mendapat kehidupan yang layak.

\section{DAFTAR PUSTAKA}

Ahmad, B. (2008). Metode Penelitian Hukum. Pustakasetia.

Gede, A. I. D., \& Putu, B. I. N. (2018). Teori-Teori Hukum. Malang: Setra Press.

Hapsari, D. R. I. (2019). Hukum dalam Mendorong Dinamika Pembangunan Perekonomian Nasional

Ditinjau dari Prinsip Ekonomi Kerakyatan. Jurnal Ilmiah Hukum, 26(2), 238-252.

Hermansyah. (2014). Kepastian Hukum dalam Penyelesaian Kredit Bermasalah. Kencana.

Maslikan, \& Sukarmi. (2018). Kewenangan Notaris dalam Pembuatan Akta Otentik Berkaitan dengan Kontrak Kerjasama. Jurnal Akta, 5(1), 11-16.

Romdonny, J., \& Rosmadi, M. L. N. (2018). Peran Media Sosial Dalam Mendukung Pemasaran Produk Organisasi Bisnis. Ikrtah Ekonomika, 1(2), 25-30.

Sari, S. W. (2016). Perkembangan dan Pemikiran Uang dari Masa ke Masa. Jurnal Ekonomi Syariah, 3(1), 39-58.

Siska, S. N. L. P., Putra, A. I. B., \& Wiratni, D. A. . S. (2019). Perlindungan Hukum terhadap Pelaku Usaha Online Shop Apabila Terjadi Wanprestasi Yang Dilakukan oleh Pemberi Jasa Endorse di Kota Denpasar. Journal Ilmu Hukum, 7(4), 1-19.

Slamet, S. R. (2013). Tuntutan Ganti Rugi dalam Perbuatan Melawan Hukum: Suatu Perbandingan dengan Wanprestasi. Lex Jurnalica (Journal of Law), 10(2), 107-120.

Sunggono, B., \& Harianto, A. (2010). Bantuan Hukum dan Hak Asasi Manusia. Bandung. Mandar Maju. 